\title{
Struktura branżowa i koncentracja przestrzenna wiodących światowych firm przemyslowych
}

Procesy transformacji przedsiębiorstw, różnorodnych branż przemysłowych a także ich przestrzennych form koncentracji, w coraz większym stopniu związane są z nasilającymi się procesami globalizacji. Procesy te w szybkim tempie zmierzają do światowej integracji produkcji, działalności poszczególnych instytucji, zwłaszcza finansowych, gospodarki regionów i krajów. Wynika to z charakteru globalizacji, która wyraża się w dążeniu do tworzenia świata bez granic gospodarczych, społecznych, informacyjnych, ekologicznych, dzięki czemu można przemieszczać strumienie kapitałowo-finansowe, produkty, surowce oraz powiązania kooperacyjne firm, idee i ludzi. Procesy te $z$ jednej strony mogą prowadzić do destabilizacji poszczególnych regionów ale z drugiej mogą dla nich stwarzać ogromne możliwości rozwoju. Współcześnie, głównym czynnikiem przyśpieszającym procesy globalizacji jest technologia informacyjna. która w coraz większym stopniu pod wieloma względami ujednolica świat oraz przyśpiesza jego rozwój gospodarczy, społeczny i kulturowy. Dzięki niej dostarczana jest coraz większa ilość informacji na tematy środowiska przyrodniczego, stosunków demograficznych, działalności firm i instytucji. W konsekwencji otrzymujemy znacznie więcej informacji aniżeli jesteśmy w stanie wykorzystać do wyjaśniania złożonej rzeczywistości przyrodniczej, gospodarczej, społecznej czy kulturowej. Prowadzi ona także do swoistego skracania czasu i przestrzeni w zakresie kontaktów między ludźmi zarządzającymi złożonymi różnorodnymi strukturami gospodarczymi, firmami, czy instytucjami. Procesowi globalizacji ekonomicznej, społecznej i kulturowej towarzyszy także proces globalizacji wartości w zakresie ocen nowych lokalizacji, rynków, jakości sprawowanej władzy $\mathrm{i}$ in. W wyniku procesu globalizacji dokonuje się integracja wielu przedsiębiorstw przemysłowych, sieci handlowych, instytucji bankowych, centrów zarządzania $\mathrm{i}$ informacji a w konsekwencji integracja ludzi na całym świecie.

W układzie przestrzennym, w zależności od regionalnych uwarunkowań, procesy te działają z różnym natężeniem. Uaktywniają one procesy polaryzacyjne różnicujące poszczególne obszary oraz wpływają na zwiększanie się między nimi dystansu cywilizacyjnego, ekonomicznego, społecznego a także coraz wyraźniej pojawiające się bariery w zakresie dostępu do zasobów informacji i wiedzy.

W wyniku procesów globalizacji kształtują się nowe struktury Unii Europejskiej a wiele krajów ubiega się o jej członkostwo. Kraje zmierzające do UE, godzą się na częściowe podporządkowanie się jednemu prawodawstwu, prowadzenie wspólnej polityki obronnej, a także np. ustaleniom Światowej Organizacji Handlu (WTO) zaleceniom Banku Światowemu, czy Międzynarodowemu Funduszowi Walutowemu. Równolegle systematycznie rośnie znaczenie wielkich ponad narodowych koncernów przemysłowych, które w zasadzie nie identyfikują się z interesami żadnego kraju ale prowadzą własną politykę 
rozwoju, zmierzając do podnoszenia swojej pozycji konkurencyjnej w drodze rozwoju badań naukowych i wprowadzania nowych produktów, opanowywania rynku, przepływu informacji, produktów, technologii itp. W konsekwencji wiele decyzji dotyczące polityki gospodarczej, które wcześniej należały do kompetencji państwa, podejmowanych jest poza jego granicami. Poszczególne ponad narodowe firmy kierują się własną logiką, którą obecnie trudno wiązać $z$ interesem jakiekolwiek państwa, czy regionu. Prowadzi to do zmiany pozycji władz państwowych w zakresie polityki gospodarczej i oddziaływania na te firmy. W globalnym świecie władze państwowe poszczególnych krajów nie mogą np. dowolnie ustalać podatków, bo konsekwencje ich decyzji nie liczących się z regułami rynku, mogą doprowadzić do ucieczki kapitału na tereny innych, dowolnie wybranych miejsc.

W świetle przedstawionych przesłanek należy przyjąć, iż globalizacja jest procesem obiektywnym, w którym musimy się nauczyć funkcjonować i zgodnie $\mathrm{z}$ jego regułami rozwijać swoją działalność gospodarczą i kulturową. Dlatego obecnie procesowi temu musimy poświęcać coraz więcej uwagi, by zrozumieć jego mechanizmy, które należy w optymalnym stopniu wykorzystać dla rozwoju gospodarczego naszego kraju a także poszczególnych regionów i układów lokalnych. W świetle przedstawionych przesłanek należy przyjąć, iż obecnie Polska a także regiony funkcjonujące $w$ integrującej się Europie mogą budować własne strategie rozwoju w oparciu o reguły silnej koncentracji nauki i technologii albo w oparciu o dyfuzję procesów rozwojowych, nasilających się w wyniku rozszerzania się przestrzennego europejskiego bieguna wzrostu.

Przyjmując, iż w procesie globalizacji wiodącą rolę odgrywają koncerny ponadnarodowe, w niniejszych rozważaniach podejmiemy analizę sektorową 50 największych firm przemysłowych świata, lokalizację siedzib ich zarządów, wielkości kapitału i pracujących. Koncerny te bowiem w znacznym stopniu wyznaczają kierunki rozwoju gospodarczego nie tylko świata ale także poszczególnych krajów i regionów. Oddziałują one także na procesy transformacji krajów Europy Srodkowej w tym i Polski. W zależności od stopnia rozeznania ich funkcjonowania oraz tendencji przemian, będzie je można także lepiej wykorzystać dla pobudzania i stymulowania wzrostu gospodarczego różnej skali układów przestrzennych.

Największe koncerny przemysłowe świata charakteryzują się dużym zróżnicowanie w zakresie wartości kapitału, który waha się od 73,3 bil. funtów angielskich w firmie japońskiej - Nippno Telegraph \& Telephone Co, zajmującą pierwszą pozycję w rankingu 50 największych światowych firm do 15,1 bil. funtów w firmie - Korea Electric Power, zajmującej wśród nich ostatnią pozycję. Łącznie koncerny te dysponują znacznymi zasobami kapitałowymi sięgającymi 1383,6 bil. funtów. Wśród 50 największych koncernów przemysłowych świata pierwszą pozycję zajmuje japoński koncern Nippon Telegraph \& Telephone Co., z dominującą w jego strukturze branżą komunikacyjną (tab. 1). Koncern ten dysponuje kapitałem 73,3 biliona funtów, który stanowi 5,3\% kapitału 50 największych światowych firm. Drugą pozycję zajmuje amerykański koncern General Motors Co., największa na świecie firma produkcji samochodów, $\mathrm{z}$ udziałami również w przemyśle lotniczym i kosmicznym oraz technice informacyjnej, z kapitałem 69,29 bln funtów, czyli 5,0\% udziału kapitału tej kategorii firm. Trzecią pozycję zajmuje japoński koncern Tokyo Electric Power, skupiający $5,0 \%$ kapitału a czwartą i piątą pozycje zajmują dwa amerykańskie koncerny General Electric $(4,6 \%)$ i Ford Motor Co. $(3,9 \%)$. Te pięć największych na świecie firm przemysłowych odgrywa dominującą rolę i skupiają łącznie aż 23,8\% ich ogólnego kapitału 50 największych koncernów, podczas gdy same stanowią 10,0\% ich zbiorowości. 
14 Tab.1. Największe firmy przemysłowe świata (1993-1994).

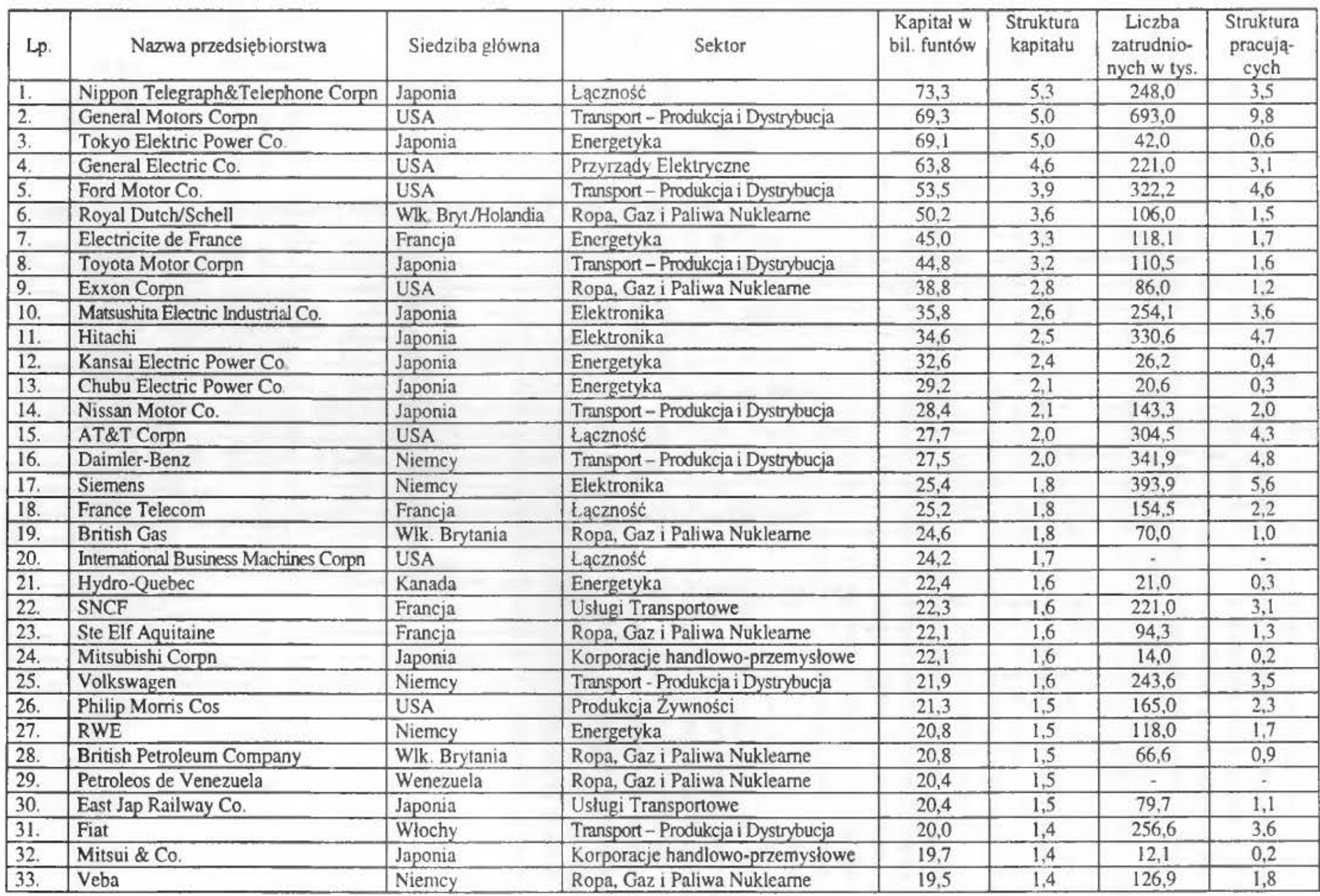




\begin{tabular}{|c|c|c|c|c|c|c|c|}
\hline 34. & Telefonika de Espana & Hiszpania & Łaczność & 18,5 & 1,3 & 103,9 & 1,5 \\
\hline 35. & GTE Corpn & USA & Lączność & 17,8 & 1,3 & 111,0 & 1,6 \\
\hline 36. & Nippon Steel Corpn & Japonia & Hutnictwo i Metalurgia & 17,8 & 1,3 & . & - \\
\hline 37. & ITOCHU Corpn & Japonia & Korporacje handlowo-przemysłowe & 17,5 & 1,3 & 7,4 & 0,1 \\
\hline 38. & $\begin{array}{l}\text { IRI-Istituto per la Ricostruzione } \\
\text { Industriale }\end{array}$ & Włochy & Finanse & 17,2 & 1,2 & 327,2 & 4,6 \\
\hline 39. & E. I. Du Pont De Nemaurs \& Co. & USA & Ropa, Gaz i Paliwa Nukleame & 17,1 & 1,2 & 327,2 & 4,6 \\
\hline 40. & BellSouth Corpn & USA & Łączność & 17,1 & 1,2 & 92,1 & 1,3 \\
\hline 41. & Toshiba Corpn & Japonia & Elektronika & 17,0 & 1,2 & 175,0 & 2,5 \\
\hline 42. & Tohoku Electric Power Co. & Japonia & Energetyka & 16,9 & 1,2 & 14,1 & 0,2 \\
\hline 43. & Sony Corpn & Japonia & Elektronika & 16,8 & 1,2 & 130,0 & 1,8 \\
\hline 44. & Mobil Corpn & USA & Ropa, Gaz i Paliwa Nuklearne & 16,7 & 1,2 & 58,5 & 0,8 \\
\hline 45 , & Sears Roebuck and $\mathrm{Co}$. & USA & Dom towarowy & 16,5 & 1,2 & - & - \\
\hline 46. & British telecommunications & Wlk. Brytania & Lączność & 16,4 & 1,2 & 148,9 & 2,1 \\
\hline 47. & ENI-Ente Nazionale Indrocarburi & Whochy & Ropa, Gaz i Paliwa Nukleame & 16,3 & 1,2 & 106,4 & 1,5 \\
\hline 48. & Kyushu Electric Power Co. & Japonia & Energetyka & 16,2 & 1,2 & 13,8 & 0,2 \\
\hline 49. & Marubeni Corpn & Japonia & Korporacje handlowo-przemyslowe & 15,7 & 1,1 & 10,0 & 0,1 \\
\hline 50. & \begin{tabular}{|l|} 
Korea Electric Power \\
\end{tabular} & Korea & Energetyka & 15,1 & 1,1 & 30,1 & 0,4 \\
\hline
\end{tabular}

Źródło: The Definitive to Business Today. The Times 1000, 1996. Times Books. 1995. 
Kolejne pozycje od szóstej do dziesiątej, zajmują: Royal Dutch/Shell, angielskoholenderskie przedsiębiorstwo petrochemiczne, Electricite de France (reprezentujące sektor energetyki), Toyota Motor Co (przemysł samochodowy), Exxon i Matsushita Electric Industrial. Te pięć kolejnych koncernów skupiają łącznie 15,5\% kapitału tej kategorii firm. Wymienione 10 największe firmy świata charakteryzują się znacznym koncentracją kapitału wynoszącym 39,3\% ogólnego kapitału tych firm, podczas gdy stanowią one $20,0 \%$ ich liczebności. Stosunkowo mniejszymi zasobami kapitałowymi od 15 bil. funtów do 30 bil. funtów, charakteryzuje się 38 koncernów, czyli 76\% ich liczebności, które łącznie skupiają $55,9 \%$ kapitału (tab. 2).

Wiodące koncerny przemysłowe świata odznaczają się także znacznym zróźnicowaniem po względem liczby pracujących, która waha się od 693 tys. pracowników w koncernie General Motors Corpn i 393,9 tys. w koncernie Siemens do 0,1 tys. w dwóch firmach japońskich Marubeni Corpn i ITOCHU, reprezentujące korporacje handlowo-przemysłowe. Wśród analizowanych firm pierwszą pozycję w strukturze rangowej zajmuje koncern General Motors Corpn skupiający $9,8 \%$ pracujących ogołu badanych firm. Kolejną grupę stanowi 7 koncernów, w których pracuje od 300 do 400 tys. pracowników (Siemens, DaimierBenz, Hitachi IRI-Intituto per la Ricostruzione Industriale, E.I. Du Pont De Nermours \& Co., Ford Motor Co., i AT \& T Corpn.). Lącznie wymienione osiem koncernów znajdujących się na czele największych firm przemysłowych świata pod względem liczby pracujących, skupiają aż $43,0 \%$ ogółu pracujących, podczas gdy stanowią one tylko $16,0 \%$ ich ogólnej liczebności (tab. 3). Natomiast pod względem wartości kapitału firmy te zajmuja odległe pozycje (wyjątkiem General Motors Corpn, który zajmuje 2 pozycję) od 11 do 39.

Znaczne zróżnicowanie kapitałowe 50 największych światowych koncernów określa stosunkowo wysoka wartość współczynnika koncentracji kapitału', który wynosi 0,203 oraz wartość współczynnika koncentracji pracujących ${ }^{2}$, który wynosi 0,3 . Podkreśla to także wartość współczynnika zmienności odchylenia standardowego, który dla wartości kapitału wynosi 55,6\% (przy średniej arytmetycznej 28,4 bil. funtów i odchyleniu standardowym 15,8 bil.) a dla liczby pracujących $88,5 \%$ (średnia arytmetyczna 153,5 tys. pracujących a odchylenie standardowe 135,8 tys.). Oznacza to, iż koncerny te odznaczają się większym zróżnicowaniem pod względem liczby pracujących aniżeli pod względem wartości kapitału.

' Wskaźnik koncentracji kapitału koncernów $\left(k_{k}\right)$ określa wzór:

$$
k_{k}=\frac{1}{200} \sum_{i=1}^{n}\left|p_{i}-k_{i}\right|
$$

gdzie: $\quad p$-procentowy udzial i-tej firmy w ogólnẹj zbiorowości badanych firm,

$k$ - procentowy udzial kapitału i-tej firmy w ogólnej wartości kapitału badanych firm.

${ }^{2}$ Wskaźnik koncentracji pracujących $\left(k_{z}\right)$ określa wzór:

$$
k_{z}=\frac{1}{200} \sum_{i=1}^{n}\left|p_{i}-z_{i}\right|
$$

gdzie: $\quad p$ - procentowy udzial i-tej firmy w ogólnej zbiorowości badanych firm,

$z$ - procentowy udział pracujących w i-tej firmy w ogólnej liczby pracujących badanych firm. 
Tab.2. Struktura wielkościowa 50 największych światowych koncernów

\begin{tabular}{|c|r|r|r|}
\hline $\begin{array}{c}\text { Przedzialy wielko- } \\
\text { ściowe w bil. funtów }\end{array}$ & Liczba koncernów & $\begin{array}{c}\text { Wielkość kapitału } \\
\text { w bil. funtów }\end{array}$ & Struktura kapitału \\
\hline $15-20$ & 19 & 325,8 & 23,6 \\
\hline $20-30$ & 19 & 447,0 & 32,3 \\
\hline $30-40$ & 4 & 141,8 & 10,2 \\
\hline $40-50$ & 2 & 89,8 & 6,5 \\
\hline $50-60$ & 2 & 103,7 & 7,5 \\
\hline $60-70$ & 3 & 202,2 & 14,6 \\
\hline $70-80$ & 1 & 73,3 & 5,3 \\
\hline Ogółem & 50 & 1383,6 & 100,0 \\
\hline
\end{tabular}

Żródło: The Definitive to Business Today. The Times 1000, 1996. Times Books. 1995.

Tab.3. Struktura wielkościowa 50 największych światowych koncernów

\begin{tabular}{|c|r|r|r|}
\hline $\begin{array}{c}\text { Przedzialy wielkości } \\
\text { pracujących }\end{array}$ & Liczba koncernów & Liczba pracujących & Struktura pracujących \\
\hline $7-50$ & 11 & 211,3 & 3,0 \\
\hline $50-100$ & 7 & 547,2 & 7,7 \\
\hline $100-150$ & 11 & 1323,0 & 18,7 \\
\hline $150-200$ & 3 & 494,5 & 7,0 \\
\hline $200-300$ & 6 & 1444,3 & 20,5 \\
\hline $300-400$ & 7 & 2347,5 & 33,2 \\
\hline $400-700$ & 1 & 693,0 & 9,8 \\
\hline Ogólem & 46 & 7060,8 & 100,0 \\
\hline
\end{tabular}

Źródło: The Definitive to Business Today. The Times 1000, 1996. Times Books. 1995.

Wyrazem zróżnicowania wielkości i zajmowanych pozycji rangowych analizowanych firm jest wartość kapitału przypadającego na jednego pracującego, która charakteryzuje się dużym zróżnicowaniem i waha się od 1645,6 tys. funtów do 52,4 tys. Najwyższymi wskaźnikami odznaczają się koncerny japońskie np. ITOCHU Corpn (2358,8),Tokyo Electric Power Co (1645,6), Mitsui \& Co (1629,5 tys.) i Mitsubishi Corpn (1580,6), Nissan Motor Co $(1415,3)$ i Chubu Electric Power Co (1245). Znacznie niższymi wskaźnikami charakteryzują się firmy pozostałych krajów. Związane jest to głównie ze wysokim stopniem robotyzacji produkcji, która prowadzi do wytwarzania najbardziej konkurencyjnych produktów, znajdujących stosunkowo łatwo popyt na rynkach światowych. Relacje między analizowanymi miernikami odzwierciedla stosunkowo wysoka wartość wskaźnika korelacji, który wynosi 0,384 .

Poszczególne branże przemysłowe w różnym stopniu są podatne na wykształcanie największych koncernów (tab.4). W świetle analizy 50 dominujących światowych koncernów okazuje się, iż głównymi branżami wykazującymi tendencje do koncentracji kapitału jest: energetyka, ropa, gaz i paliwa nuklearne, telekomunikacja oraz transport, produkcja i dystrybucja.

Pierwsze miejsce wśród branż przemysłowych, pod względem wartości kapitału, zajmuje energetyka, która w 9 firmach skupia aż 18,6\% kapitału tej kategorii firm (tab. 4). 
Wśród nich na czoło wysuwa się firma Tokyo Electric Power, zajmująca wśród 50 największych w świecie koncernów - 3 pozycję i skupiająca $5,0 \%$ ich ogólnego kapitału, kolejne miejsce w tym sektorze i 7 pozycję, wśród tej kategorii firm zajmuje Electricite de France, 12 pozycję zajmuje Kansai Electric Power i 13 pozycję Chubu Electric Power.

Tab.4. Struktura branżowa największych 50 firm przemysłowych świata (według wartości kapitału)

\begin{tabular}{|l|r|r|r|}
\hline \multicolumn{1}{|c|}{ Sektor } & Liczba firm & \multicolumn{1}{c|}{$\begin{array}{c}\text { Kapital w bil. } \\
\text { funtów }\end{array}$} & Struktura kapitału \\
\hline Energetyka & 9 & 267,3 & 19,3 \\
\hline Transport - Produkcja i Dystrybucja & 7 & 265,4 & 19,2 \\
\hline Ropa, Gaz i Paliwa Nuklearne & 10 & 246,6 & 17,8 \\
\hline Lączność & 8 & 220,2 & 15,9 \\
\hline Elektronika & 5 & 129,7 & 9,4 \\
\hline Korporacje handlowo-przemysłowe & 4 & 75,0 & 5,4 \\
\hline Przyrzady Elektryczne & 1 & 63,8 & 4,6 \\
\hline Usługi Transportowe & 2 & 42,7 & 3,1 \\
\hline Produkcja Żywności & 1 & 21,3 & 1,5 \\
\hline Hutnictwo i Metalurgia & 1 & 17,8 & 1,3 \\
\hline Finanse & 1 & 17,2 & 1,2 \\
\hline Dom towarowy & 1 & 16,5 & 1,2 \\
\hline Ogółem & 50 & 1383,6 & 100,0 \\
\hline
\end{tabular}

Źrodło: The Definitive to Business Today. The Times 1000, 1996. Times Books. 1995.

Wśród branż przemysłowych drugie miejsce zajmują firmy związane z eksploatacją przetwórstwem, przesyłaniem ropy naftowej i gazu ziemnego oraz z paliwami nuklearnymi. Lącznie 10 firm tego sektora koncentruje $17,4 \%$ kapitahu. Wśród nich dominującą pozycje zajmuje firma Royal Dutch/Shell, skupiająca 3,6\% wartości kapitału największych na świecie firm przemysłowych a $w$ ogólnym rankingu zajmuje 5 pozycję, następnie: Exxon ( 9 pozycja), British Gaz (19 pozycja) i Ste Elf Aquitaine (23 pozycja). W najbliźszych latach należy przyjąć, iż mimo wielkiego wzrostu kapitałowego w branży energetycznej i technikach informacyjnych, zaopatrywanie w energię będzie nadal siłą napędową największych firm światowych.

Trzecie miejsce zajmują firmy reprezentujące sektor łączności. W 7 firmach tego sektora skupia się $15,5 \%$ wartości kapitału największych firm. W tej grupie znajduje się największa firma światowa Nippon Telegraph \& Telephone, która koncentruje aż 5,3\% wartości kapitału 50 największych światowych firm. Kolejne miejsce w tym sektorze zajmują: AT\&T (15 pozycja), France Telewcom (18 pozycja) oraz Internationaln Business Machines (20 pozycja).

Czwarte miejsce zajmują przedsiębiorstwa związane z produkcja i dystrybucja środków transportu. Sektor ten skupia 9 firm, które łącznie obejmują aż 14,3\% wartości ich ogólnego kapitału. Jest on reprezentowany przez koncerny samochodowe, wśród których najpoważniejszą pozycję zajmuje Genaral Motors. Firma ta zajmuje drugą pozycję wśród 50 największych firm przemysłowych swiata i skupia 5,0\% ich kapitału. Kolejne miejsce zajmuje Ford Motor, zajmujący wśród analizowanych firm 5 pozycję i skupiający 3,0\% 
kapitału oraz Toyota Motor ( 8 pozycja), Nissan Motor (14 pozycja), Dainier-Benz (16 pozycja), Volksawagen ( 25 pozycja). Również firmy motoryzacyjne będą się rozwijać i nadal pozostają przemysłem o światowym znaczeniu.

Miejsce piąte zajmują firmy reprezentujące elektronikę, która w 6 firmach skupia 13,4\% ogólnego kapitału największych światowych firm,. Reprezentują ją: Matsuschita Electric Industrial (10 pozycja), Siemens (17 pozycja) i Sony (43 pozycja). Należy wnosić, iż wraz z dalszym nasilaniem się informacyjnej fazy rozwoju społecznego, na produkty tego typu firm popyt będzie coraz bardziej wzrastał.

Pięć wymienionych branż przemysłowych odznacza się najsilniejszymi tendencjami do tworzenia coraz bardziej zorganizowanych $\mathrm{i}$ coraz większych korporacji przemysłowych a skupiają one łącznie aż 79,1\% kapitału 50 największych światowych koncernów. Stąd należy je uznać jako podstawowe lokomotywy rozwoju gospodarczego świata. Znaczącą rolę odgrywają także firmy wielobranżowe, które łącznie obejmują 11,4\% ich kapitału ${ }^{3}$.

Mniejszą rolę odgrywają branże, które nie stwarzają warunków do silnej koncentracji swojej działalności i stąd reprezentowane tylko przez jedną firmę. Reprezentuje je: produkcja żywności, hutnictwo, obsługa finansowa oraz sklepy i łącznie skupiają $5,0 \%$ kapitału.

Wyraźnie zmienia się struktura rangowa firm w świetle liczby pracujących. Pod tym względem na czoło wysuwa się branża transportu, produkcji i dystrybucji, w której siedem koncernów skupia się aż $29,9 \%$ ogółu pracujących, podczas gdy same obejmują tylko $14 \%$ ich liczebności. Kolejną pozycję zajmuje elektronika $(18,2 \%)$, łączność $(16,5 \%)$ i ropa, gaz i paliwa nuklearne. W wymienionych czterech branżach przemysłowych skupia się łącznie $79,4 \%$ ogółu pracujących (tab. 5) ${ }^{4}$. Poszczególne branże przemysłowe odznaczają się różnym stopniem koncentracji kapitału i pracujących. Pod względem kapitału pierwszą pozycję i dominujące znaczenie ma energetyka, która skupia aż $20,5 \%$ jego wartości, natomiast pod tym względem liczby pracujących zajmuje dopiero piątą pozycję ( $5,7 \%$ pracujących). Transport, produkcja i dystrybucja pod względem udziału pracujących zajmuje pierwszą pozycję i obejmuje $29,9 \%$, a drugą pozycję pod względem udziału kapitału $(20,3 \%)$. Trzecia pozycję pod względem pracujących zajmuje elektronika $(18,2 \%)$, podczas gdy pod względem udziału kapitału zajmuje dopiero piątą pozycję $(9,9 \%)$. Wynika to $\mathrm{z}$ różnej kapitałochłonności stanowisk pracy poszczególnych branż przemysłowych. Szczególnie kapitałochłonne stanowiska pracy występują $w$ japońskich korporacjach handlowoprzemysłowych, gdzie na jednego pracującego przypada 1724,4 tys. funtów a następnie w energetyce $(661,8$ tys.). Wynika to $\mathrm{z}$ duzego stopnia robotyzacji produkcji oraz kosztownych elektrowni i sieci przesyłowych energii elektrycznej. Natomiast najmniej kosztowne stanowiska pracy występują w obsłudze finansowej firm $(52,7$ tys.), elektronice $(101,1$ tys.)

\footnotetext{
${ }^{3}$ Przykładem koncernu wielobranżowego może być Hyundai, w którego strukturze występuje wiele branż. Branża motoryzacyjna (ósma pod względem sprzedaży samochodów w 1999 r.) obejmowała 4 firmy i w strukturze koncernu obejmowała $32,4 \%$ ogólnej wartości sprzedaży koncernu; przemysi ciężki z naftowym reprezentowany przez 11 firm (największy producent statków) dostarczał 23,8\% wartości sprzedaży; sektor finansów i usług - 23,2\%; branża budowlano-montażowa (Hyundai Engineering and Construction, 12 na liście światowych eksporterów tego typu usług) dostarczała 14,0\% ogólnej sprzedaży; branża elektrotechniczna (drugi na świecie producent pamięci DRAM) dostarczała 6,5\% ogólnej sprzedaży całej firmy (Hyundaj, dane z 1997 i z 1999 r., za „Wprost" 9 stycznia 2000). ${ }^{4}$ Cztery firmy nie podaly liczby pracujących, stąd dokonane porównanie kapitału i pracujących odnoszą się do 46 firm.
} 
i produkcji żywności $(129,1$ tys.). Oznacza to, iż przy braku kapitału rozwijanie tego typu działalności może dać najlepsze efekty gospodarcze.

Tab.5. Kapitał i pracujący w 50 największych firmach przemysłowych świata

\begin{tabular}{|l|r|r|r|r|r|r|}
\hline \multicolumn{1}{|c|}{ Sektor } & $\begin{array}{c}\text { Liczba } \\
\text { firm }\end{array}$ & $\begin{array}{c}\text { Kapitat w } \\
\text { bil. funtów }\end{array}$ & $\begin{array}{c}\text { Struktura } \\
\text { kapitału }\end{array}$ & $\begin{array}{c}\text { Liczba } \\
\text { zatrudnio- } \\
\text { nych } \\
\text { w tys. }\end{array}$ & $\begin{array}{c}\text { Struktura } \\
\text { pracuja- } \\
\text { cych }\end{array}$ & $\begin{array}{c}\text { Kapital na } \\
\text { 1 pracuja- } \\
\text { cego } \\
\text { w tys. }\end{array}$ \\
\hline Energetyka & 9 & 267,3 & 20,5 & 403,9 & 5,7 & 661,8 \\
\hline $\begin{array}{l}\text { Transport - Produkcja } \\
\text { i Dystrybucja }\end{array}$ & 7 & 265,4 & 20,3 & 2111,1 & 29,9 & 125,7 \\
\hline $\begin{array}{l}\text { Ropa, Gaz i Paliwa } \\
\text { Nuklearne }\end{array}$ & 9 & 226,1 & 17,3 & 1041,9 & 14,8 & 217,0 \\
\hline Lączność & 7 & 196,0 & 15,0 & 1162,9 & 16,5 & 168,5 \\
\hline Elektronika & 5 & 129,7 & 9,9 & 1283,6 & 18,2 & 101,1 \\
\hline $\begin{array}{l}\text { Korporacje handlowo- } \\
\text { przemyslowe }\end{array}$ & 4 & 75,0 & 5,7 & 43,5 & 0,6 & 1724,4 \\
\hline Przyrzady Elektryczne & 1 & 63,8 & 4,9 & 221,0 & 3,1 & 288,8 \\
\hline Usługi Transportowe & 2 & 42,7 & 3,3 & 300,7 & 4,3 & 142,0 \\
\hline Produkcja Żywności & 1 & 21,3 & 1,6 & 165 & 2,3 & 129,1 \\
\hline Finanse & 1 & 17,2 & 1,3 & 327,2 & 4,6 & 52,7 \\
\hline Ogółem & 46 & 1304,6 & 100,0 & 7060,8 & 100,0 & 184,8 \\
\hline
\end{tabular}

Źródło: The Definitive to Business Today. The Times 1000, 1996. Times Books. 1995.

Największe firmy świata odznaczają się dużym skupieniem koncentracji przestrzennej swoich zarządów, które w podstawowym stopniu decydują o rozmiarach i przemieszczaniu się kapitałów oraz o wyborze odpowiednich strategii rozwoju koncernów. Największe ich skupienie występuje w Japonii, na terenie której swoją siedzibę ma najwięcej, bo 18 firm tej kategorii i łącznie skupiają one aż $38,2 \%$ ich kapitału (tab. 6,7). Drugą pozycję zajmuja Stany Zjednoczone skupiające w 12 firmach $27,7 \%$ kapitalu. Na pierwszych pozycjach czołowych światowych koncernów znaczną przewagę mają więc firmy japońskie i amerykańskie. Wśród pierwszych największych 15 firm znajduje się bowiem aż 8 firm japońskich, 5 Stanów Zjednoczonych oraz po jednej firmie z Wielkiej Brytani/Halandii i Francji.

Znacznie mniejsza liczba firm występuje na terenie Niemiec (8,3\% kapitału analizowanych koncernów), Francji (8,3\%), Wielkiej Brytanii $(8,1 \%)$ a w dalszej kolejności znajdują się Włochy $(3,9 \%)$ oraz Wenezuela , Hiszpania i Korea.

Spośród 50 światowych koncernów Europę reprezentuje tylko I6. Na ich czele znajduje się francuskie przedsiębiorstwo Electricite de France, które zajmuje siódmą pozycję. W tej grupie koncernów, Francję reprezentują: France Telecom (18 miejsce) SNCF koncern kolejowo-stoczniowy (22 miejsce), które są własnością państwa oraz Ste Elf Aquitaine. 
Tab.6. Koncentracja kapitału w 50 największych firm przemysłowych świata

\begin{tabular}{|l|c|c|c|}
\hline \multicolumn{1}{|c|}{ Kraj } & Liczba firm & Kapitał w bil. funtów & Struktura \\
\hline Japonia & 18 & 527,9 & 38,2 \\
\hline USA & 12 & 383,8 & 27,7 \\
\hline Niemcy & 5 & 115,2 & 8,3 \\
\hline Francja & 4 & 114,6 & 8,3 \\
\hline W. Brytania & 4 & 112,0 & 8,1 \\
\hline Włochy & 3 & 53,6 & 3,9 \\
\hline Kanada & 1 & 22,4 & 1,6 \\
\hline Wenezuela & 1 & 20,4 & 1,5 \\
\hline Hiszpania & 1 & 18,5 & 1,3 \\
\hline Korea & 1 & 15,1 & 1,1 \\
\hline Ogólem & 50 & 1383,6 & 100,0 \\
\hline
\end{tabular}

Źródlo: The Definitive to Business Today. The Times 1000, 1996. Times Books. 1995.

Tab.6. Koncentracja kapitału w 50 największych firm przemysłowych świata

\begin{tabular}{|l|r|r|r|r|r|r|}
\hline \multicolumn{1}{|c|}{ Kraj } & Liczba firm & $\begin{array}{c}\text { Kapitał w } \\
\text { bil. funtów }\end{array}$ & Struktura & $\begin{array}{c}\text { Liczba } \\
\text { pracujących } \\
\text { w tys. }\end{array}$ & $\begin{array}{c}\text { Struktura } \\
\text { pracujących }\end{array}$ & $\begin{array}{c}\text { Kapital na 1 } \\
\text { pracującego }\end{array}$ \\
\hline Japonia & 17 & 510,1 & 39,1 & 1631,4 & 23,1 & 312,7 \\
\hline USA & 10 & 343,1 & 26,3 & 2380,5 & 33,7 & 144,1 \\
\hline Niemcy & 5 & 115,2 & 8,8 & 1224,3 & 17,3 & 94,1 \\
\hline Francja & 4 & 114,6 & 8,8 & 587,9 & 8,3 & 194,9 \\
\hline W. Brytania & 4 & 112,0 & 8,6 & 391,5 & 5,5 & 286,1 \\
\hline Włochy & 3 & 53,6 & 4,1 & 690,2 & 9,8 & 77,7 \\
\hline Kanada & 1 & 22,4 & 1,7 & 21,0 & 0,3 & 1067,5 \\
\hline Hiszpania & 1 & 18,5 & 1,4 & 103,9 & 1,5 & 177,6 \\
\hline Korea & 1 & 15,1 & 1,2 & 30,1 & 0,4 & 501,9 \\
\hline Ogółem & 46 & 1304,6 & 100,0 & 7060,8 & 100,0 & 184,8 \\
\hline
\end{tabular}

Źródło: The Definitive to Business Today. The Times 1000, 1996. Times Books. 1995.

Do tej grupy należy także pięć koncernów niemieckich. Wśród nich najwyższą pozycję zajmuje Daimler-Benz (16 miejscu), Siemens (17 miejsce), Volkswagen największy w Europie producent samochodów zajmuje 25 pozycję i Veba ( 33 pozycja). Zbliżony udział kapitałowy mają koncerny angielskie. Obok wspomnianego Royal/ Dutch/Shell (zajmującego 6 pozycję), reprezentuje ją: British Gaz (19 pozycja), British Petroleum Co (28 pozycja) i British Telecommunications (46 pozycja).

Wśród włoskich koncernów najwyższą pozycję zajmuje FIAT (31) IRI (38) oraz ENIEnte Nazionale Indrocarburi - koncern petrochemiczny (47) a jedyny koncern hiszpański Telefonica de España zajmuje 34 pozycję.

Porównując koncentrację zarządów firm, ich kapitał i liczbę pracujących należy podkreślić, iż znaczna przewaga udziału kapitału nad udziałem pracujących zaznacza się w koncernach japońskich, które wynoszą odpowiednio 39,1\% i 23,1\%, zbliżony udział tych cech zaznacza się na terenie Francji, natomiast w firmach występujących na terenie Niemiec, Wielkiej Brytanii oraz Stanów Zjednoczonych zaznacza się większy udział pracują- 
cych aniżeli udział kapitału (tab. 8). Zróżnicowane udziały w pozostałych krajach związane są ze specyfiką branżową reprezentujących je pojedynczych firm (Korea, Hiszpania, Kanada, Włochy).

Wiodące światowe koncerny przemysłowe reprezentujące określone branże wykazują różne prawidłowości w zakresie przestrzennej lokalizacji swoich zarządów (tab. 8). Jedne branże charakteryzują się znacznym skupieniem i występują głównie na terenie danego kraju, inne zaś wykazują tendencje do bardziej równomiernego występowania na terenie wielu krajów.

Wielkie wielobranżowe koncerny handlowo-przemysłowe, występują wyłącznie na terenie Japonii - 4. Dużym stopniem koncentracji przestrzennej charakteryzują się także koncerny reprezentujące elektronikę. Spośród 5 tego typu firm, aż zarządy 4 firm mają swoją siedzibę na terenie Japonii. Podobnie, spośród 9 firm energetycznych, $5 \mathrm{z}$ nich związana jest $\mathrm{z}$ Japonią. Znacznym stopniem koncentracji przestrzennej charakteryzują się także firmy związane $z$ telekomunikacją. Spośród 8 firm tego typu, 4 występuje na terenie Stanów Zjednoczonych a pozostałe są rozproszone i występują na terenie: Japonii, Francji, Włoch i Hiszpanii.

Mniejszym stopniem koncentracji odznaczają się koncerny związane $\mathrm{z}$ ropą naftową. gazem i paliwami nuklearnymi. Z 10 firm tego typu po trzy występuje na terenie Stanów Zjednoczonych i Wielkiej Brytanii, a po jednej w Niemczech, Francji, Kanadzie i Wenezueli. Natomiast największym rozproszeniem charakteryzują się koncerny reprezentujące transport, produkcję i dystrybucję, które w zbližonej ilości występują na terenie Japonii ( 3 koncerny), Stanów Zjednoczonych i Niemiec (po 2 koncerny) oraz po jednym we Francji i Włoszech..

W świetle przestrzennej koncentracji kapitału największych firm przemysłowych okazuje się, iż w skali globalnej występują zasadniczo dwa dominujące bieguny wzrostu społeczno-gospodarczego, Japonia i Stany Zjednoczone z Kanadą. Łącznie na ich obszarze skupia się aż 31 firm, które obejmują aż 67,5\% kapitału. Natomiast na terenie krajów europejskich skupia się od jednej do pięciu takich firm.

W tej sytuacji kraje Europy Zachodniej maja dwie drogi rozwoju, albo jako samodzielne państwa funkcjonować na marginesie dwöch wspomnianych światowych biegunów wzrostu albo połączyć swój potencjał i stworzyć trzeci, europejski biegun wzrostu o znaczeniu światowym. W wyniku podejmowanych stopniowo wspólnych decyzji, kraje europejskie postanowiły wybrać drugi wariant, tworząc wspólnie trzeci biegun wzrostu. Łącznie kraje te (Niemcy, Francja, Wielka Brytania, Włochy, Hiszpania) obejmują 17 firm, które skupiają 29,9\% kapitału, czyli wspólnie pod tym względem dorównują potencjału gospodarczemu Japonii i Stanom Zjednoczonym. Wyróżnione trzy światowe bieguny wzrostu w układzie globalnym odgrywają decydującą rolę. Z 50 największych firm światowych na ich terenie występują siedziby zarządów aż 48 koncernów, które obejmują łącznie 97,4\% ich kapitału.

Rozwój gospodarczy światowych biegunów wzrostu społeczno-gospodarczego, dokonuje się w warunkach nasilającej się konkurencji. Dokonuje się ona głównie między występującymi na ich terenie największymi koncernami. Tym działaniom podporządkowana jest więc polityka ekonomiczna rządów tych krajów. Przejawem tego jest $m$.in. wojna handlowa między USA i Japonią, która nasila się, zwłaszcza w zakresie penetracji rynków zbytu. Problematyką tę próbują rozwiązywać organizacje międzynarodowe, które w powiązaniu 
z decydentami politycznymi tych państw organizują częste spotkania przedstawicieli kół politycznych, gospodarczych i biznesu. O znacznym wpływie sektora gospodarczego na politykę ekonomiczną świadczy fakt, iż np. w czasie wyborów prezydenckich w USA, często kartą przetargową staje się handel między Japonią a Stanami Zjednoczonymi oraz stosowane wzajemne sankcje handlowe. Znaczną barierą w tym zakresie jest $\mathrm{m}$. in. z jednej duża hermetyczność rynku japońskiego na produkty pochodzące ze Stanów Zjednoczonych (np. w handlu samochodami, urządzeniami elektronicznymi) a z drugiej stosunkowo bardziej liberalny rynek amerykański w zakresie popytu na produkty japońskie. Przejawia się to $w$ deficycie handlowym między Japonią a Stanami Zjednoczonymi, co w konsekwencji znacznie osłabiają pozycję konkurencyjną amerykańskich przedsiębiorstw.

W stosunku do światowych biegunów wzrostu społeczno-gospodarczego Polska przez najbliższe lata znajdować się będzie na ich peryferiach. Stąd mamy dwa warianty budowy strategii naszego rozwoju gospodarczego. Jeden, to kreować na swoim terenie warunki dla rozwoju nowoczesnych produktów opartych o zasoby nauki i technologii a drugi to pozostawać jako peryferyjny układ gospodarczy integrującej się Europy, który kształtował się będzie w oparciu o reguły komplementarnego rozwoju. W obecnych uwarunkowaniach najkorzystniejsze jest przyjęcie reguł rozwoju obu wariantów. Wykorzystując reguły rozwoju opartego o zasoby nauki i techniki należy rozwijać edukację, która jest obecnie podstawowym czynnikiem rozwoju i wdrażania nowych technologii informacyjnych. Równocześnie należy zmierzać do stwarzania korzystnych warunków napływu kapitału związanego z największymi światowymi koncernami przemysłowymi, których lokalizacje zakładają dhuższe cele strategiczne i w mniejszym stopniu związane są z bardzo mobilnym kapitałem spekulacyjnym.

Początkowo poszczególne regiony muszą zmierzać do podnoszenia swojej pozycji konkurencyjnej w zakresie podejmowania a także rozwijania produkcji i usług w oparciu o reguły komplementarne związane nie tylko $\mathrm{z}$ napływem kapitału zagranicznego ale także skuteczniejszym pobudzaniem wewnętrznych zasobów finansowych ludności. Jest to możliwe poprzez lepiej zorganizowane instytucje bankowe oraz instrumenty prawne zachęcających społeczeństwo do oszczędzania. Ważne są tu także wkraczające inwestycje związane z najpoważniejszymi koncernami przemysłowymi, które charakteryzują się: znacznymi kapitałami, wysokim poziomem konkurencyjności, nowoczesną bazą wytwórczą oraz w miarę ustabilizowaną siecią rynkową.

Konieczne są przy tym działania na szczeblu władzy publicznej preferującej rozwój badań podstawowych i aplikacyjnych w wybranych dziedzinach, które w najbliższej przyszłości będą miały coraz lepsze warunki rozwoju. Należą do nich np. produkty informatyczne, laserowe, światłowodowe, czy ekologiczne produkty rolnicze w zakresie których występują już znaczące osiągnięcia a także rozwijania prac związanych z doskonaleniem metod zarządzania różnymi układami przestrzennymi, a szczególnic układami regionalnymi i lokalnymi.

Natomiast w perspektywie rozwoju należy założyć dążenie do zmniejszania się udziału powiązań komplementarnych na rzecz rozwoju regionalnych centrów wzrostu społeczno-gospodarczego opartych o reguły silnej koncentracji nauki i technologii. 
Tab.8. Struktura branzowa 50 najwiẹkszych firm przemysłowych świata według krajów

\begin{tabular}{|c|c|c|c|c|c|c|c|c|c|c|c|c|c|}
\hline Kraje & Ogółem & $\begin{array}{l}\text { Elek- } \\
\text { tronika }\end{array}$ & $\begin{array}{l}\text { Ener- } \\
\text { getyka }\end{array}$ & Finanse & $\begin{array}{l}\text { Hut- } \\
\text { nictwo } \\
\text { i Meta- } \\
\text { lurgia }\end{array}$ & $\begin{array}{l}\text { Lacz- } \\
\text { nosć }\end{array}$ & $\begin{array}{l}\text { Produk- } \\
\text { cja } \\
\text { Żywno- } \\
\text { ści }\end{array}$ & $\begin{array}{l}\text { Przy- } \\
\text { rzady } \\
\text { Elek- } \\
\text { tryczne }\end{array}$ & $\begin{array}{l}\text { Ropa, } \\
\text { Gaz } \\
\text { i Paliwa } \\
\text { Nukle- } \\
\text { ame }\end{array}$ & $\begin{array}{l}\text { Domy } \\
\text { towa- } \\
\text { rowe }\end{array}$ & $\begin{array}{l}\text { Trans- } \\
\text { port } \\
\text { Produk- } \\
\text { cja } \\
\text { i Dys- } \\
\text { trybucja }\end{array}$ & $\begin{array}{l}\text { Ushugi } \\
\text { Trans- } \\
\text { portowe }\end{array}$ & $\begin{array}{c}\text { Korpo- } \\
\text { racje } \\
\text { handlo- } \\
\text { wo- } \\
\text { przemy- } \\
\text { słowe }\end{array}$ \\
\hline Japonia & 18 & 4 & 5 & & 1 & 1 & & & & & 2 & 1 & 4 \\
\hline USA & 12 & & & & & 4 & 1 & 1 & 3 & 1 & 2 & & \\
\hline Niemcy & 5 & 1 & 1 & & & & & & 1 & & 2 & & \\
\hline Francja & 4 & & 1 & & & 1 & & & 1 & & & 1 & \\
\hline W. Brytania & 4 & & & & & 1 & & & 3 & & 1 & & \\
\hline W'ochy & 3 & & & 1 & & & & & 1 & & & & \\
\hline Kanada & 1 & & 1 & & & & & & & & & & \\
\hline Wenezuela & I & & & & & & & & 1 & & & & \\
\hline Hiszpania & 1 & & & & & 1 & & & & & & & \\
\hline Korea & 1 & & 1 & & & & & & & & & & \\
\hline Ogółem & 50 & 5 & 9 & 1 & 1 & 8 & 1 & 1 & 10 & 1 & 7 & 2 & 4 \\
\hline
\end{tabular}

艺 Z Źródło: The Definitive to Business Today. The Times 1000, 1996. Times Books. 1995. 